Journal of Engineering and Applied Sciences 15 (6): 1426-1430, 2020

ISSN: 1816-949X

(C) Medwell Journals, 2020

\title{
Rainfall Analysis of the Makassar City using Thiessen Polygon Method Based on GIS
}

\author{
${ }^{1}$ Sudirman Nganro, ${ }^{2}$ Slamet Trisutomo, ${ }^{3}$ Roland A. Barkey and ${ }^{2}$ Mukti Ali \\ ${ }^{1}$ Department of Architecture, Faculty of Engineering, \\ ${ }^{2}$ Laboratory of Waterfront City, Faculty of Engineering, Hasanuddin University, \\ 92173 Gowa indonesia \\ ${ }^{3}$ Laboratory of Planning and Forestry Information System, Faculty of Forestry, \\ Hasanuddin University, 90245 Makassar, Indonesia
}

\begin{abstract}
Precipitation is the descent of water from the atmosphere to the surface of the earth which is usually rain, snow, fog, dew and hail, the amount of water falling on the surface of the earth can be measured by rain gauges, the distribution of rain in the space can be known by measuring rain in some locations and areas reviewed. In a variety of human activities, rainfall becomes one of the data needs, especially in the study of water availability for consumption, irrigation building planning and mapping of flooded areas. This study aims to analyze local rainfall data on research objects by utilizing global weather data, the observation period for 15 years i.e., from 2000-2014. This research using Thiessen polygon method based on Geographic Information System (GIS) application, rainfall data sourced from global wheater, accessed on August 28, 2017. The results showed that the distribution of rainfall in the research object is represented by 2 rainfall stations, namely station p_521194 and station p_521197. The highest maximum daily rainfall occurred in 2002 of $149.80 \mathrm{~mm}$ while the lowest occurred in 2008 amounted to $68.76 \mathrm{~mm}$. Rainfall data will be used to analyze flood discharge in Makassar city.
\end{abstract}

Key words: Rainfall analysis, Thiessen polygon method, GIS, Makassar city, availability, geographic

\section{INTRODUCTION}

Regional rainfall should be estimated from some rainfall observation points. One method of calculating rainfall is the polygon Thiessen method (Singh, 2013; Booij, 2005; El-Khoury et al., 2015; Gibbs et al., 2016), this method takes into account the weight of each station that represents the surrounding area, the Thiessen polygon is fixed for a particular rain station network, if there is a change of rain station network, again a new polygon. Rain is a form of precipitation of water vapor coming from clouds in the atmosphere, rainfall occurs due to evaporation of water, especially water from the surface of the rising sea water into the atmosphere and cools, then distills and falls partly into the sea and partly on land, Water rain falling on the land, partly seeping into the soil (infiltration), partially retained by plants (intercept), partly evaporating and partly moist (Cho, 2016).

Inundated rainfall flows as surface runoff, some falling on the flat surface will form a retention basin while the other leads to a lower area and falls into the channel. The water in the reservoirs, canals and seas will also undergo evaporation, condensation, so that, it becomes sublimated to rain and fall back, this process is called the hydrologic cycle. Rain can be divided into three types based on the process of precipitation, i.e., convection rain, orographic rain and frontal rain. Rainfall unit measured in $\mathrm{mm} / \mathrm{inch}, 1 \mathrm{~mm}$ rainfall means rain water that falls after $1 \mathrm{~mm}$ does not flow, not pervasive and does not evaporate. The precipitation required for the preparation of a water use design and flood control design is the average rainfall in the whole area concerned, not rainfall at a particular point, this rainfall is called regional rainfall and is expressed in mm. Sudirman stated that one of the factors that affect the flood/inundation is rainfall.

This study aims to calculate the rainfall of Makassar city region using the Thiessen polygon method based on Geographic Information System (GIS) application.

\section{MATERIALS AND METHODS}

Research object: The study is located in the Makassar city of the capital of South Sulawesi province, geographically the city of Makassar lies between

Corresponding Author: Sudirman Nganro, Department of Architecture, Faculty of Engineering, Hasanuddin University, 92173 Gowa, Indonesia 


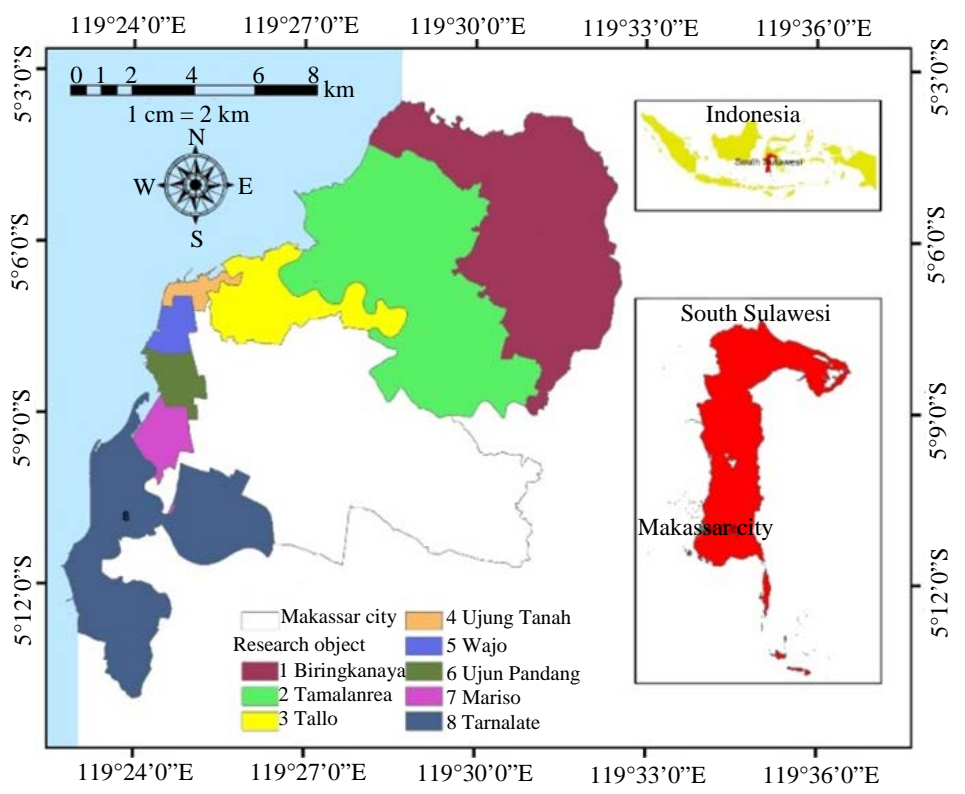

Fig. 1: Research object

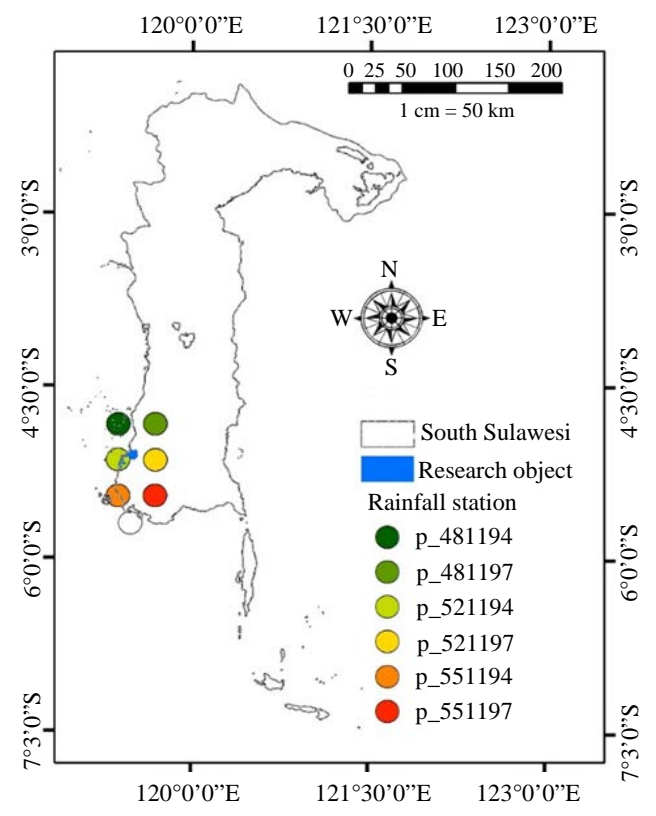

Fig. 2: Rainfall station

1190'36”-119³2'59” East Longitude (EL) and between 454'36”-58' 19” South Latitude (SL). Research object as shown in Fig. 1.

Research data sources: The data used to calculate rainfall in Makassar city is sourced from http://globalweather.tamu.edu/accessed on August, 28, 2017, precipitation data downloaded from January 1st 2000-July 31th 2014 (15 years) consisting of 6

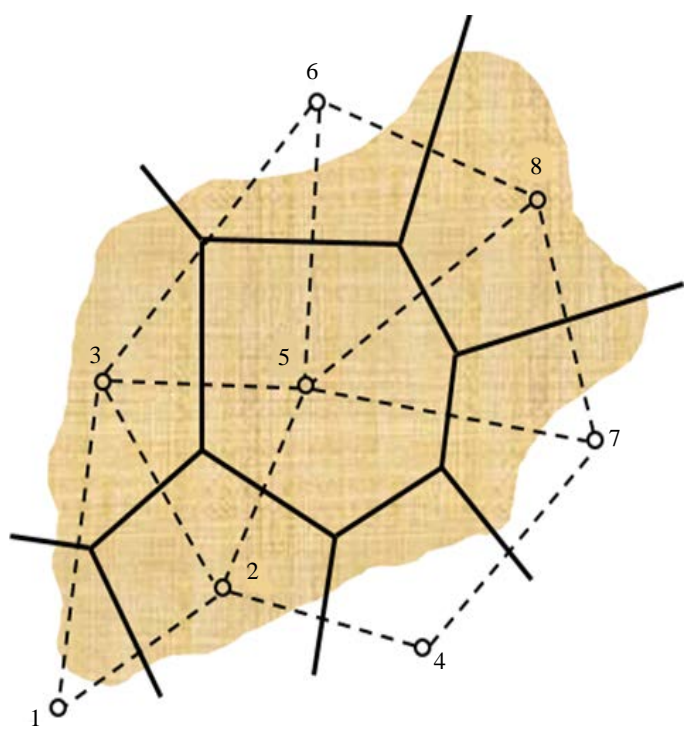

Fig. 3: Thiessen polygon method

observation stations and located at the decimal coordinates -4.8283 , 199.7125 North-East corner up to $-5.7581,119.2511$ South-West corner. The position of the rainfall station is shown in Fig. 2.

Thiessen polygon method: If the observation points within the area are not evenly distributed, then the mean rainfall calculation is done by taking into account the area of influence of each observation point. On an area within the watershed it is assumed that the rain is the same as that at the nearest station, so that, the recorded rain at a 
station represents that area (Triatmodjo, 2013; Yekti, Permana, 2007; Kawet, Halim, 2013). Rainfall in the area can be calculated by the following Eq. 1:

$$
\overline{\mathrm{R}}=\frac{\mathrm{A} 1 \mathrm{R} 1+\mathrm{A} 2 \mathrm{R} 2+, \ldots,+\mathrm{AnRn}}{\mathrm{A} 1+\mathrm{A} 2+, \ldots, \mathrm{An}}
$$

Where:

$$
\overline{\mathrm{R}} \quad \text { : Rainfall area }
$$

$\mathrm{R} 1, \mathrm{R} 2, \ldots, \mathrm{Rn}$ : Rainfall in each observation point and $\mathrm{n}$ is the number of observation points

$\mathrm{A} 1, \mathrm{~A} 2, \ldots, \mathrm{An}:$ The area representing the station 1, $2,3, \ldots, n$

Figure 3 shows that the area of rain measured by an observation is limited by broken lines.

\section{RESULTS AND DISCUSSION}

The rain gauge only provides the depth of rain on which the station is located, so that, rain on an area should be estimated from that point of measurement. Thiessen polygon method is one method that can be used to calculate the average rainfall in an area. This study uses
6 observation points consisting of stations p_481194, p_481197, p_521194, p_521197, p_551194 and p_551197. Based on the results of the analysis, the distribution of rainfall along with its limits are presented in Figure 4 which are grouped by color. The color shows the representation of the rainfall station on the map.

Figure 4 shows the distribution of rainfall at the research location based on Thiessen polygon, from the figure is calculated the area represented by each station that are p_521194 and p_521197. The area is shown in Fig. 5.

The distribution of rainfall in Fig. 4 shows that the station p_521194 represents the polygon in green. The monthly rainfall data as shown in Table 1.

The polygon with the brown color in Fig. 4 is the distribution of rainfall that represents the station p_521197. The rainfall data is shown in Table 2.

By using the Thiessen polygon method in Eq. 1, the rainfall of the research object can be analyzed, as informed in Table 3.

Based on the results of the analysis in Table 3, it can be described graph of rainfall research object as shown in Fig. 6.

\begin{tabular}{|c|c|c|c|c|c|c|c|c|c|c|c|c|c|}
\hline \multirow[b]{2}{*}{ Years } & \multicolumn{12}{|l|}{ Month } & \multirow{2}{*}{$\begin{array}{c}\text { Max. } \\
\text { rainfall } \\
\text { (mm/day) }\end{array}$} \\
\hline & Jan. & Feb. & Marc. & Apr. & May & June & July & Aug & Sept & Oct. & Nov. & Dec. & \\
\hline 2000 & 73.83 & 90.40 & 80.26 & 23.70 & 10.08 & 60.85 & 17.24 & 21.24 & 0.00 & 25.71 & 41.58 & 58.68 & 90.40 \\
\hline 2001 & 74.12 & 83.20 & 91.39 & 18.84 & 15.66 & 103.18 & 12.74 & 6.38 & 10.33 & 17.35 & 45.94 & 63.64 & 103.18 \\
\hline 2002 & 151.37 & 46.22 & 62.00 & 25.87 & 17.37 & 16.74 & 4.60 & 1.21 & 4.68 & 4.52 & 39.41 & 36.98 & 151.37 \\
\hline 2003 & 56.95 & 85.84 & 26.67 & 22.23 & 9.36 & 13.17 & 7.71 & 8.50 & 5.31 & 15.01 & 26.11 & 71.62 & 85.84 \\
\hline 2004 & 60.66 & 66.87 & 84.05 & 13.88 & 53.09 & 3.85 & 8.88 & 0.00 & 4.48 & 3.46 & 86.55 & 74.63 & 86.55 \\
\hline 2005 & 51.07 & 121.71 & 47.83 & 88.33 & 25.24 & 8.71 & 19.46 & 16.76 & 3.76 & 23.40 & 34.33 & 62.20 & 121.71 \\
\hline 2006 & 65.11 & 68.70 & 55.86 & 36.99 & 106.39 & 65.99 & 9.31 & 1.04 & 0.00 & 0.00 & 32.13 & 73.79 & 106.39 \\
\hline 2007 & 74.65 & 53.75 & 63.79 & 39.42 & 42.15 & 105.09 & 2.28 & 13.65 & 7.52 & 18.86 & 22.71 & 81.90 & 105.09 \\
\hline 2008 & 68.85 & 62.13 & 37.15 & 22.32 & 16.28 & 17.21 & 8.10 & 9.56 & 3.32 & 31.48 & 46.77 & 34.60 & 68.85 \\
\hline 2009 & 84.54 & 57.95 & 22.91 & 18.54 & 11.72 & 8.33 & 25.44 & 1.48 & 13.76 & 1.37 & 23.06 & 53.19 & 84.54 \\
\hline 2010 & 88.49 & 26.16 & 25.99 & 22.19 & 16.37 & 11.48 & 77.44 & 27.60 & 41.07 & 38.40 & 34.93 & 105.65 & 105.65 \\
\hline 2011 & 106.83 & 71.69 & 54.04 & 54.21 & 54.25 & 3.65 & 6.29 & 5.20 & 2.72 & 15.41 & 55.09 & 50.55 & 106.83 \\
\hline 2012 & 79.54 & 39.31 & 58.36 & 20.30 & 5.32 & 23.38 & 13.37 & 1.28 & 11.59 & 13.18 & 10.04 & 17.06 & 79.54 \\
\hline 2013 & 136.43 & 60.23 & 63.00 & 66.32 & 81.54 & 68.91 & 43.40 & 12.75 & 4.59 & 8.79 & 18.82 & 77.96 & 136.43 \\
\hline 2014 & 61.96 & 53.25 & 9.33 & 27.52 & 94.59 & 120.23 & 27.00 & 0.00 & 0.00 & 0.00 & 0.00 & 0.00 & 120.23 \\
\hline
\end{tabular}

Table 1: Rainfall of station p_521194

\begin{tabular}{|c|c|c|c|c|c|c|c|c|c|c|c|c|c|}
\hline \multirow[b]{2}{*}{ Years } & \multicolumn{12}{|c|}{ Month } & \multirow{2}{*}{$\begin{array}{c}\text { Max. } \\
\text { Rainfall } \\
\text { (mm/day) }\end{array}$} \\
\hline & Jan. & Feb. & Marc. & Apr. & May & June & July & Aug. & Sept. & Oct. & Nov. & Dec. & \\
\hline 2000 & 41.84 & 49.54 & 46.66 & 36.58 & 17.34 & 91.30 & 20.34 & 27.93 & 5.86 & 36.67 & 25.68 & 48.08 & 91.30 \\
\hline 2001 & 54.12 & 72.75 & 32.48 & 35.72 & 32.68 & 61.62 & 2.81 & 3.70 & 9.28 & 13.26 & 32.96 & 55.64 & 72.75 \\
\hline 2002 & 118.50 & 19.92 & 23.77 & 44.64 & 19.11 & 15.35 & 5.24 & 2.06 & 8.98 & 6.30 & 40.14 & 34.76 & 118.50 \\
\hline 2003 & 38.63 & 43.61 & 22.21 & 18.62 & 18.63 & 9.10 & 11.25 & 13.37 & 4.07 & 27.21 & 35.63 & 67.90 & 67.90 \\
\hline 2004 & 24.86 & 70.28 & 47.58 & 24.61 & 37.19 & 11.66 & 13.68 & 3.31 & 11.12 & 10.29 & 71.89 & 23.33 & 71.89 \\
\hline 2005 & 8.51 & 60.34 & 34.00 & 37.71 & 19.37 & 7.89 & 25.53 & 12.77 & 6.64 & 33.51 & 33.70 & 51.97 & 60.34 \\
\hline 2006 & 70.63 & 37.98 & 19.35 & 15.48 & 99.23 & 43.62 & 5.60 & 2.04 & 0.00 & 4.32 & 10.82 & 30.93 & 99.23 \\
\hline 2007 & 28.90 & 50.20 & 22.75 & 22.59 & 40.00 & 142.13 & 13.77 & 11.85 & 10.76 & 26.14 & 39.11 & 75.50 & 142.13 \\
\hline 2008 & 66.99 & 38.75 & 27.11 & 22.13 & 16.58 & 29.34 & 8.13 & 16.48 & 4.79 & 44.44 & 19.38 & 24.24 & 66.99 \\
\hline 2009 & 48.62 & 38.36 & 11.25 & 23.09 & 19.93 & 15.83 & 30.00 & 0.00 & 13.49 & 36.38 & 20.57 & 29.57 & 48.62 \\
\hline 2010 & 68.39 & 35.64 & 30.52 & 22.92 & 47.56 & 24.15 & 139.11 & 46.89 & 38.15 & 37.01 & 34.72 & 83.96 & 139.11 \\
\hline 2011 & 77.85 & 40.18 & 92.91 & 26.91 & 114.46 & 5.49 & 5.88 & 5.11 & 3.51 & 12.08 & 33.29 & 30.59 & 114.46 \\
\hline 2012 & 44.75 & 10.62 & 22.60 & 30.68 & 8.87 & 49.76 & 18.78 & 0.00 & 3.26 & 12.03 & 13.95 & 14.65 & 49.76 \\
\hline 2013 & 140.99 & 45.79 & 71.99 & 100.36 & 86.72 & 59.32 & 21.85 & 7.19 & 0.00 & 5.33 & 1.84 & 51.69 & 140.99 \\
\hline 2014 & 39.50 & 30.09 & 5.95 & 1.86 & 58.18 & 93.57 & 6.20 & 0.00 & 0.00 & 0.00 & 0.00 & 0.00 & 93.57 \\
\hline
\end{tabular}

Table 2: Rainfall of station p 521197 
J. Eng. Applied Sci., 15 (6): 1426-1430, 2020

Table 3: Rainfall analysis using thiessen polygon method

\begin{tabular}{|c|c|c|c|c|c|c|c|}
\hline \multirow[b]{3}{*}{ Years } & \multicolumn{2}{|c|}{ Station p_521194 } & \multicolumn{2}{|c|}{ Station p_521197 } & \multirow{4}{*}{$\begin{array}{c}\text { Area x Rainfall } \\
(\mathrm{A} 1 . \mathrm{R} 1)+(\mathrm{A} 2 . \mathrm{R} 2) \\
6\end{array}$} & \multirow{4}{*}{$\begin{array}{c}\text { Total of polygon } \\
\text { areas (Ha) } \\
\text { A1+A2 } \\
7\end{array}$} & \multirow{4}{*}{$\begin{array}{c}\text { Rainfall }(\mathrm{mm}) \\
\hat{\mathrm{R}}=6: 7 \\
8\end{array}$} \\
\hline & $\begin{array}{l}\text { Polygon } \\
\text { areas (Ha) }\end{array}$ & $\begin{array}{l}\text { Rainfall } \\
\text { (mm) }\end{array}$ & $\begin{array}{l}\text { Polygon } \\
\text { areas (Ha) }\end{array}$ & $\begin{array}{l}\text { Rainfall } \\
\text { (mm) }\end{array}$ & & & \\
\hline & A1 & $\mathrm{R} 1$ & A2 & R2 & & & \\
\hline 1 & 2 & 3 & 4 & 5 & & & \\
\hline 2000 & $11,283.66$ & 90.40 & 565.52 & 91.30 & $1,071,672.58$ & $11,849.18$ & 90.44 \\
\hline 2001 & $11,283.66$ & 103.18 & 565.52 & 72.75 & $1,205,334.90$ & $11,849.18$ & 101.72 \\
\hline 2002 & $11,283.66$ & 151.37 & 565.52 & 118.50 & $1,775,042.04$ & $11,849.18$ & 149.80 \\
\hline 2003 & $11,283.66$ & 85.84 & 565.52 & 67.90 & $1,007,001.73$ & $11,849.18$ & 84.98 \\
\hline 2004 & $11,283.66$ & 86.55 & 565.52 & 71.89 & $1,017,220.46$ & $11,849.18$ & 85.85 \\
\hline 2005 & $11,283.66$ & 121.71 & 565.52 & 60.34 & $1,407,434.60$ & $11,849.18$ & 118.78 \\
\hline 2006 & $11,283.66$ & 106.39 & 565.52 & 99.23 & $1,256,540.57$ & $11,849.18$ & 106.04 \\
\hline 2007 & $11,283.66$ & 105.09 & 565.52 & 142.13 & $1,266,220.63$ & $11,849.18$ & 106.86 \\
\hline 2008 & $11,283.66$ & 68.85 & 565.52 & 66.99 & $814,765.87$ & $11,849.18$ & 68.76 \\
\hline 2009 & $11,283.66$ & 84.54 & 565.52 & 48.62 & $981,356.95$ & $11,849.18$ & 82.82 \\
\hline 2010 & $11,283.66$ & 105.65 & 565.52 & 139.11 & $1,270,797.19$ & $11,849.18$ & 107.25 \\
\hline 2011 & $11,283.66$ & 106.83 & 565.52 & 114.46 & $1,270,140.25$ & $11,849.18$ & 107.19 \\
\hline 2012 & $11,283.66$ & 79.54 & 565.52 & 49.76 & $925,686.60$ & $11,849.18$ & 78.12 \\
\hline 2013 & $11,283.66$ & 136.43 & 565.52 & 140.99 & $1,619,198.51$ & $11,849.18$ & 136.65 \\
\hline 2014 & $11,283.66$ & 120.23 & 565.52 & 93.57 & $1,409,495.43$ & $11,849.18$ & 118.95 \\
\hline
\end{tabular}

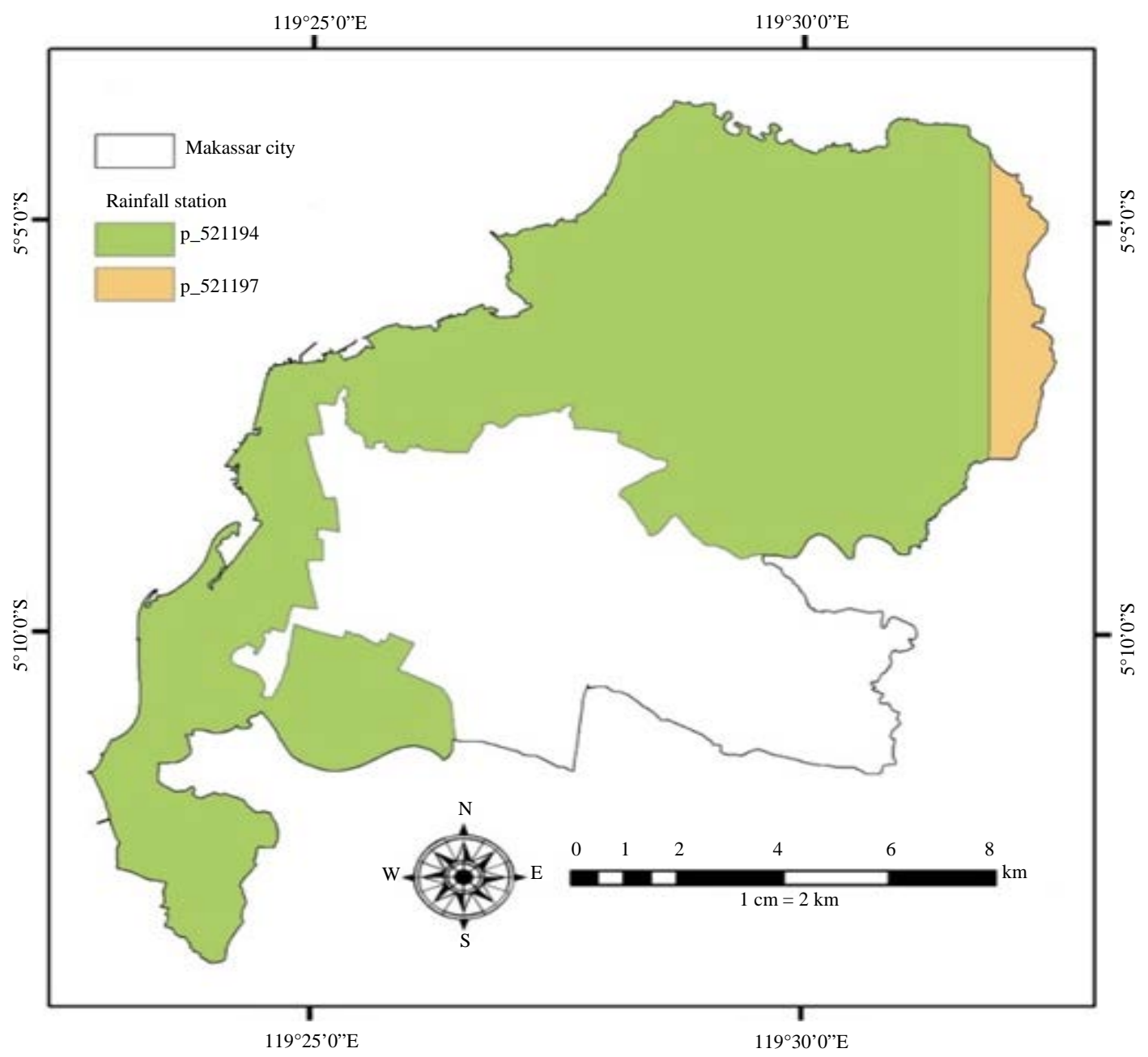

Fig. 4: Rainfall distribution based on research object 


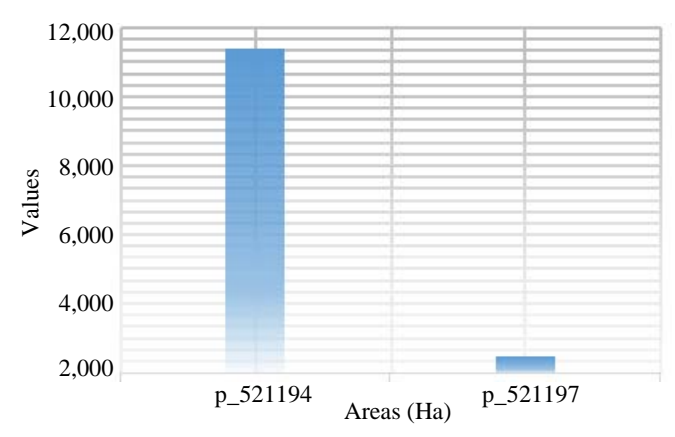

Fig. 5: The area that represents the station

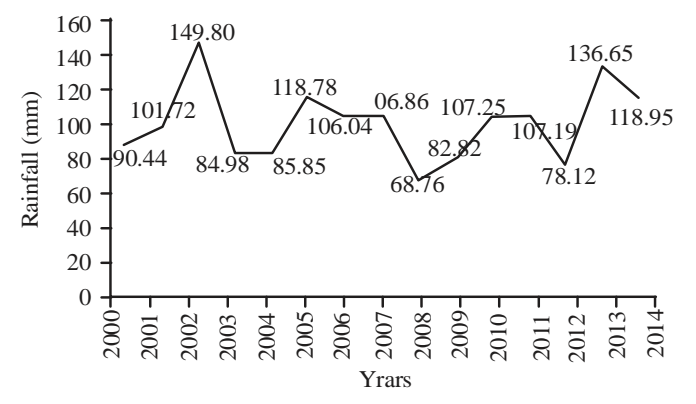

Fig. 6: Rainfall chart of the research object

\section{CONCLUSION}

A period of observation for 15 years, i.e., from 2000-2014. The results show that the distribution of rainfall is grouped into 2 polygons each representing stations P_521194 and p_521197. Based on the results of the analysis, the data show that the highest rainfall occurred in 2002 which amounted to $149.80 \mathrm{~mm}$ while rainfall the lowest occurrence in 2008 of $68.76 \mathrm{~mm}$.

\section{ACKNOWLEDGEMENT}

The researchers would like to thank ESRI Indonesia for providing ArcGis 10.5 Software to support the implementation of this research.

\section{REFERENCES}

Booij, M.J., 2005. Impact of climate change on river flooding assessed with different spatial model resolutions. J. Hydrol., 303: 176-198.

Cho, S.E., 2016. Stability analysis of unsaturated soil slopes considering water-air flow caused by rainfall infiltration. Eng. Geol., 211: 184-197.

El-Khoury, A., O. Seidou, D.R. Lapen, Z. Que, M. Mohammadian, M. Sunohara and D. Bahram, 2015. Combined impacts of future climate and land use changes on discharge, Nitrogen and Phosphorus loads for a Canadian river Basin. J. Environ. Manage., 151: 76-86.

Gibbs, M.S., K. Clarke and B. Taylor, 2016. Linking spatial inundation indicators and hydrological modelling to improve assessment of inundation extent. Ecol. Indic., 60: 1298-1308.

Singh, B.R., 2013. Climate Change: Realities, Impacts Over Ice Cap, Sea Level and Risks. IntechOpen, Rijeka, Croatia, ISBN: 978-953-51-0934-1, Pages: 508. 